\title{
Perspectives on Health: Working with Communities as Cultural Anthropologists and Bioarchaeologists
}

\author{
Samantha L. Purchase
}

\begin{abstract}
AвSTRACT The anthropological study of health has always been an integral part of the discipline. With the development of cultural anthropology and physical anthropology (specifically, bioarchaeology) in the nineteenth century came different theories and methodologies concerning the study and definition of communities. Still today, cultural anthropology and bioarchaeology share the same broad goals of exploring the evolving relationships between experiences of health and the community, culture, and environment (being natural, domestic, political, and social). That cultural anthropologists study extant cultures and bioarchaeologists do not has necessitated the evolution of different methodological practices. Here, I explore some of the differences between these two subdisciplines: their differing notions of community, how they engage with communities, and the relevance of their work to the communities they study. I contextualize this analysis with a short discussion of the sub-disciplines' co-evolution and ground it with examples from my research with middle Holocene Siberian, Russian Federation, and Anglo-Saxon to Post-Industrial British communities.
\end{abstract}

KEYWords Health; morbidity, community, physical, bioarchaeology

"The task of bridging the three bodies — individual, social, and political — remains the missing link in a critical discourse on illness." (Scheper-Hughes, 1994, p. 239)

In the anthropological study of health, individual and community-level experiences are explored to further understand the cultures they both form and are formed by. These generalizations allow comparisons to be made between cultures across time and space (Rosman \& Rubel, 1995, p. 5). Working within time and space has created different sub-disciplines within anthropology. This report explores how cultural anthropology and physical anthropology (specifically, bioarchaeology) define and engage with the communities they study and how their study of health is of relevance therein. This exploration is grounded within my training and experience as a paleopathologist and draws on my work with skeletal populations from middle Holocene Siberia, Russian Federation, and Anglo-Saxon to Post-Industrial Britain. The evolution of the disciplines will first be discussed to help define the changing notion of community.

Anthropology has its roots in eighteenth-century Europe, when Enlightenment philosophers challenged entrenched political and religious beliefs and the European rediscovery of the so-called New World confronted ethnocentrism (Rosman \& Rubel, 1995). 
Revolutionary schools of thought mixed with Classics, History, and Geology (Peoples \& Bailey, 1997; Trigger, 2006), culminating the following century in the advent of anthropology. Cultural evolution, or the Darwinian theory that cultures evolve or devolve over time following a series of increasingly complex stages, was the prevailing school of thought (Freeman, 1974; Taylor, 1874). The observations used to support this theory, however, were generally acquired second-hand (e.g., Morgan, 1877). Thus, early anthropologists had little or no contact with the communities they deemed to analyze. Concomitantly, American and European medical doctors, anatomists, and other scientists began excavating mortuary sites, to study human remains, and to speculate on the health of skeletal and mummified individuals (Jones, 1876; Matthews et al., 1893). By 1886, the first paleopathology manual was published by William Whitney and, by 1910, Sir Marc Armand Ruffer had defined paleopathology as the scientific study of disease in archaeological human and non-human remains (Aufderheide \& RodríguezMartín, 1998).

The trained anthropologists of the early twentieth century ushered in cultural relativism. Anthropologists such as Franz Boas emphasized the importance of studying a culture's history and language, and of conducting one's observations in the field (Boas, 1940, 1928; Stocking, 1974). This school of thought was echoed within physical anthropology, though known under different names: culture-historical archaeology (popularized by Gustaf Kossinna and V. Gordon Childe) (Childe, 1929; Trigger, 2006) and social biology (Angel, 1946). C. Aufderheide and Conrado Rodríguez-Martín (1998) argue that before the first world war, skeletal and mummified individuals were still considered to be "curiosities" (p. 3) and true scientific rigor was inconsistently applied. As with other anthropological studies, Nationalism tainted much of the work done by physical anthropologists. The work of Earnest A. Hooton, Alfred V. Kidder and, later, of J. Lawrence Angel went on to change much of this. The former two exploring mortality and morbidity through the lenses of culture, demography, ecology, and heritage (Hooton, 1930; Kidder, 1924), and the latter studying pathology at the individual and population-levels (Angel, 1946).

British anthropologists reacted differently than their American colleagues to cultural evolution, and the early twentieth century in Britain saw the rise of functionalism or "the New Anthropology" (Malinowski, 1935; Radcliffe-Brown, 1952). This was later adopted by American anthropologists, archaeologists (calling it processualism) (Willey and Phillips, 2001), and physical anthropologists (calling it "the New Physical Anthropology") (Washburn, 1953, 1951). Functionalism promotes positivism, or objective truths derived from material evidence as tested by the scientific method (Buikstra et al., 2011; Rosman \& Rubel, 1995). Years of fieldwork were now required of anthropologists, as culture was understood to be more complex than previously thought. Physical anthropologists concerned with the study of past human culture via human remains, now calling themselves bioarchaeologists in the Americas (Blakely, 1977; Buikstra, 1977) and osteoarchaeologists in Britain and Europe (Møller-Christensen, 1973), believed that mortuary contexts mirrored the ideologies of the cultures that produced them (Binford, 1971; O'Shea, 1984). Studies of health emphasized the close associations between health, epidemiology, and demography (Aufderheide \& Rodríguez-

Engaged Scholar Journal: Community-Engaged Research, Teaching, and Learning 
Martín, 1998). However, archaeology as a whole was preoccupied with questions of human behaviour, subsistence, and social complexity rather than health (Binford, 1971, 1962), an issue that prevails today (Buikstra et al., 2011).

The mid-twentieth century also saw French anthropologist Claude Lévi-Strauss harken back to Franz Boas' work with linguistics and theorize that cultures (like languages) were composed of unconscious systems (such as kinship, mythology, and ceremony) that created larger, meaningful structures. This school of thought is called structuralism (Lévi-Strauss, 1955). Archaeologists were slower to adopt these theories. Change did not occur until the 1980s, with a similar theory called post-processualism (Hodder, 1982a, 1982b). Where processualism was objective and material, the latter was subjective and agency driven. Contrary to processualists, post-processualists believed mortuary contexts reflected the agency of those who created them. Thus, a burial could reflect practical considerations rather than the wishes of the deceased (Hodder, 1982a, 1982b).

Today, anthropology engages in postmodernism, in which no one theory, methodology, or perspective is central to the subject. The structuralism of Boas and Lévi-Strauss persists, and the concept of agency has expanded to recognize that there is a plurality of perspectives within any one culture (Rosman \& Rubel, 1995). Thus, ethnographies now sometimes include reactions to the work by members of the community, or deconstructive or discursive reflections by the ethnographer on their own culture or work (Rosman \& Rubel, 1995). Physical anthropology, or more specifically, bioarchaeology, also embraces a multiplicity of theories, methodologies, and perspectives. However, contemporary bioarchaeology (especially in Britain) is often accused of focusing too much on individual case studies and not enough on community-level interpretation (Mays, 1997; Roberts \& Manchester, 2005).

Engagement with descendant communities (a.k.a. community or collaborative archaeology) is one of — and arguably the — most socially and culturally meaningful archaeological practice to have risen from postmodernism. In this practice, archaeologists engage with members of a community descendant from that being studied archaeologically, to decolonize their research and re-empower the descendant community with agency over their culture's history. This practice represents the culmination of fifty years of shifting political, social, (see TRCC, 2015; UN, 2007) and archaeological (e.g., Agbe-Davies, 2014; Colwell, 2016; Shackel, 2014) perspectives on the rights of Indigenous peoples. It recognizes Indigenous peoples' rights to self-determination and that descendant communities are those most-qualified to interpret their own cultures. It exists at the intersection of the anthropological and archaeological practices of community engagement; and exemplifies the disciplines' parallel evolutions and shared values and goals.

In the sphere of health, both disciplines recognize the important role clinical medicine plays in grounding their work in scientific fact. At the same time, both try to move beyond the bounds of clinical reductionism to explore the evolving relationships between experiences of health and the community, culture, and environment (being natural, domestic, political, and social). In this way, all sub-disciplines of anthropology attempt to naturalize (Scheper-Hughes, 1994) the concept of health by embodying it with human experience. 
Time is the fundamental difference between the cultures studied by cultural anthropologists and bioarchaeologists. Participant observation is only possible when observing extant cultures and so, archaeologists must study what remains: material culture. This means inferring health from historical documents, human remains, and artifacts (such as examining soil samples for parasites, e.g., Cho et al., 2017).

Consequently, bioarchaeologists define community differently than cultural anthropologists. Abraham Rosman and Paula G. Rubel (1995) explain that the communities studied by early anthropologists were chosen for being naturally small. They were believed to be representative of the larger culture and were composed of people who self-identified as community members (Rosman \& Rubel, 1995, p. 11). Today, it is believed that a culture cannot be defined by a community. Rather, a culture is composed of multiple communities, and studying cultural evolution requires the synthesis of multiple ethnographic works (Rosman \& Rubel, 1995). What community is selected for ethnographic study is often based on the social problem being investigated (Rosman \& Rubel, 1995).

Bioarchaeologists cannot select communities to study in the same way. Human remains come from various sources (e.g., cemeteries associated with a parish or asylum; mass graves associated with a battle or plague; or deviant burials associated with crime or taboo). No one source (called a skeletal population or assemblage) provides an unbiased or complete representation of the wider population. To begin, the demographic distribution of those who are deceased is influenced by invisible biological, socio-economical, and environmental risk factors (discussed further below). With the aid of mathematics, the degree to which certain types of skeletal populations (attritional or infectious) are representative of the wider living population can be roughly calculated (e.g., Wood et al., 2002). Cemeteries also often represent an accumulation of the deceased over time. This means that people buried side-by-side may have died centuries apart and, therefore, have experienced different risk factors affecting their morbidity and mortality. Finally, Roberts and Manchester (2005) highlight that it is rare for entire cemeteries to be excavated. Financial, personnel, and site access limitations, as well as ethical and legal considerations (such as the North American Graves Protection and Repatriation Act in the United States), often result in partial excavation. This is ethically sound; it leaves the dead unmolested and allows for more advanced excavation and data collection methods to be used in the future should further excavation be required (Roberts \& Manchester, 2005). Intrinsically, skeletal populations are not wholly representative of the living community/ies.

This is not to say that bioarchaeologists do not, or cannot, study communities. Human remains and their mortuary contexts are imbued with communal and cultural ideology (Buikstra et al., 2011). The postmodern bioarchaeologist balances processual and postprocessual theory to interpret mortuary contexts and modern bioarchaeological, clinical, and forensic methodologies to study the remains therein. With the help of history and engagement with descendant communities, skeletal populations are reintegrated into their communities' narrative. Thus, bioarchaeologists, like cultural anthropologists, work from the level of the individual to the community, to the culture. Unlike cultural anthropologists, their efforts involve only one type of evidence: physical. 
Bioarchaeologists can engage past communities in two ways. Firstly, they can work as a part of the team that excavates the mortuary site. This is often the case in instances of cultural resource management (a.k.a., commercial archaeology), in which a mortuary site happens to be part of the archaeological survey area (such as the discovery of multiple mortuary sites along the proposed High Speed 2 [HS2] railway line in Britain) (Addley, 2018); or, in instances of academic archaeology, in which a mortuary site is the subject of an ongoing research project (e.g., Baikal-Hokkaido Archaeology Project, University of Alberta). In these instances, the degree to which individual skeletons or mummies are studied varies based on the ethics of the country in which the project is based, the ethics and laws of the country in which the work is being done, and the timeline, resources, and goals of the project.

Secondly, in countries that do not have laws surrounding the repatriation and reburial of human remains (such as England), skeletal populations are often stored at universities (like the Department of Archaeology's Human Skeletal Collection, University of Sheffield) or other institutions (such as the Centre for Human Bioarchaeology, Museum of London). Here, skeletal populations are curated and accessible for research. It was the culture-historical archaeologists of the early twentieth century who first recognized the importance of amassing large, comparative collections of human remains; the most iconic example being Aleš Hrdlička for his formation of the comparative collection at the Smithsonian Institution, United States (Buikstra et al., 2011). In Britain today, the repatriation of human remains is much debated (Simpson, 2002). Without such collections, however, it is difficult for researchers to access large skeletal populations that allow for significant discussions of community-level health. Still, this postmodernist self-reflection speaks well for the type of agency bioarchaeologists wish to have in the twenty-first century.

Therefore, to answer a research question, bioarchaeologists first select (a) past community/ ies to study and then which skeletal population(s) this is/are best represented by. Some skeletal populations are too large to be studied by a single researcher or within the project's timeline. Here, a representative sample of the skeletal population is selected. This is common practice and is often done randomly to avoid sampling bias. This practice is similar in theory to the cultural anthropological practice of handing out a survey or questionnaire to a sample of a community. I will endeavor to illustrate these interactions presently with examples from my work.

My Master's research involved investigating the morbidity of hunter-fisher-gatherer communities living in the Baikal region of Siberia, Russian Federation on either side of the climatic shift of the middle Holocene (Purchase, 2016; Purchase et al., 2019). As a member of the Baikal-Hokkaido Archaeology Project based out of the University of Alberta, Canada, I had access to the skeletal collection housed at Irkutsk State University. From this, I selected three skeletal populations to study for the periods to which they belonged, their large size, their level of preservation, and the amount of published research available for comparison. I chose one large skeletal population from before the climate changed and two smaller ones from after. In this way, I could compare the health of the skeletal populations and reflect on the risk factors that influenced their morbidity. 
The bioarchaeological study of health (paleopathology), however, carries with it an intrinsic problem - the Osteological Paradox — and this affects how bioarchaeologists interact with the communities they study. The landmark publication of James W. Wood and colleagues (1992) lays-out the following issues for paleopathologists working with skeletal populations: "demographic non-stationarity, selective mortality, and unmeasured, individual-level heterogeneity in the risks of disease and death" (p. 343). In short, the age at death distribution in non-stationary populations is more likely to reflect fertility rate rather than mortality rate; the deceased represent those who succumbed to their mortality risk factors (biological, socioeconomical, or environmental) rather than those who experienced those same risk factors and survived; and it is impossible to know the risk factors experienced by individuals at any given age, because they are archaeologically invisible (Wood et al., 1992). The problems of selective mortality and invisible heterogeneity in risk are issues with which I have dealt.

To compensate for the Osteological Paradox, I was conscientious of referring to those with non-specific infection-induced lesions as those who likely suffered from chronic infections, rather than those who suffered from acute infections. Compared to those with chronic infections, individuals who suffer from acute infections recover quickly or die. Therefore, acute infections are less likely to affect the bone and, consequently, can be archaeologically invisible. I also did not assume that chronic infections were the cause of death for such individuals, but that these infections were, instead, an additional risk factor contributing to the individuals' physiological stress levels and morbidity (Wood et al., 1992). Finally, while it cannot be known what risk factors affected an individual at any specific age, the presence of chronic infection within the wider population can be an indicator of broad risk factors within and around a culture. I was mindful of framing my discussion of risk factors at the community level rather than the individual (Roberts \& Manchester, 2005). Ultimately, I compared my results to those of other researchers and to what is known about the cultures' lifeways. In doing so, I formed generalizations about the health of the wider hunter-fisher-gatherer communities, their relationships with the environment, and their abilities to adapt.

My current research also concerns studying human morbidity in times of transition. Specifically, I am interested in the levels of mastoid infection, maxillary sinus infection, and rib lesions indicating lower respiratory infection in British skeletal populations from the AngloSaxon to Post-Industrial periods (see Purchase, 2018; Purchase et al., 2020). Broadly, this research project investigates the same anthropological themes as my Master's, but through a different lens. Here, I compensate for individual heterogeneity in risk by taking a life history approach to my study of mastoiditis and assess health in terms of frailty and morbidity (see DeWitte, 2014; Marklein et al., 2016).

Like the works of cultural anthropologists since the early twentieth century (Rosman \& Rubel, 1995), bioarchaeologists must synthesize multiple reports to understand a subject. It has been recognized since the rise of the "New Anthropology" that it takes multiple perspectives on a subject, community, culture, or theme to adequately capture the complexity of the human experience. In this vein, I am assessing the respiratory health of multiple skeletal populations from various periods to learn more about shifts in community health following shifts in 
environmental risk factors throughout time. I am adding to my work on the subject and that of other anthropologists.

Ultimately, the postmodern anthropologist is only satisfied if their work is of relevance. Luckily, even seemingly "blue sky" anthropological health research has practical applications. Rosman and Rubel (1995) highlight that many cultural anthropologists become advocates for the communities they study, giving-back in very tangible ways. This goes for bioarchaeologists, too. While the communities they study are no longer living, their research themes are still of relevance (e.g., poverty, pollution, and climate change) and inform not only their politics, but also the impact of their work. The behaviour of illness is best understood through the lenses of diverse communities from various physical and temporal contexts. Paleopathologists, for example, continuously advance the clinical understanding of infections, as they study the natural progression of disease in pre-antibiotic communities (Roberts \& Manchester, 2005).

By engaging with communities, past and present, anthropologists lead the social and scientific discussion concerning the relationship between the environment and human culture; their findings inform public health discussions, policies, and laws (Dennis, 2013; Fahlman, 2019; Kiefer, 2007; Page-Reeves et al., 2013; Stellmach et al., 2018); and they have the power to affect meaningful social change (Campbell, 2011; Kiefer, 2007). In studying respiratory health in communities that inhabited various environments, I hope to contribute to our understanding of the health impacts of pollution and poverty. Such a discussion can inform social and environmental policies and regulations in light of the current global change in climate.

In the end, the anthropological study of the past is still actively engaged in the present. By moving from a study of the individual to the community and the culture, both cultural anthropology and bioarchaeology naturalize the study of health and become the "missing link" Scheper-Hughes (1994, p. 239) longs for in the opening quotation. Such research is only possible by engaging with diverse communities across time and space with a multiplicity of perspectives.

\section{About the Author}

Samantha Purchase is a second-year Ph.D. student in the department of archaeology, University of Sheffield (UK). She completed her master of arts and bachelor of arts - high honours - degrees in the Department of Archaeology and Anthropology, University of Saskatchewan (Canada), and has worked as an archaeological technician in Eastern Ontario. Email: Slpurchase-manchester1@sheffield.ac.uk 


\section{References}

Addley, E. (2018, October 26). 'Story of a nation': HS2 archaeological dig begins in UK's biggest excavation. The Guardian. Retrieved from https://www.theguardian.com/science/2018/ oct/26/story-of-a-nation-hs2-rail-archaeological-dig-begins-in-uks-biggest-excavation.

Agbe-Davies, A.S. (2014). Community engagement in archaeology. In Encyclopedia of Global Archaeology. New York, NY: Springer.

Angel, J. L. (1946). Social biology of Greek culture growth. American Anthropologist, 48(4), 493-553.

Aufderheide, C., \& Rodríguez-Martín, C. (1998). The Cambridge Encyclopedia of Human Paleopathology. Cambridge, UK: Cambridge University.

Binford, L. (1962). Archaeology as anthropology. American Antiquity, 28(2), 217-225.

Binford, L. (1971). Mortuary practices: Their study and their potential. Memoirs of the Society of American Archaeology, 25, 6-29.

Blakely, R.L. (1977). Biocultural Adaptation in Prehistoric America. Athens, GA: University of Georgia.

Boas, F. (1928). Anthropology and Modern Life. New York, NY: Dover.

Boas, F. (1940). Race Language and Culture. London, UK: University of Chicago.

Buikstra, J.E., Baadsgaard, A., \& Boutin, A.T. (2011). Introduction. In Breathing New Life into the Evidence of Death: Contemporary Approaches to Bioarchaeology (pp. 3-26). Santa Fe, NM: School for Advanced Research.

Buikstra, J.E. (1977). Biocultural dimensions of archaeological study: A regional perspective. In Biocultural Adaptation in Prehistoric America (pp. 67-84). Athens, GA: University of Georgia.

Campbell, D. (2011). Anthropology's contribution to public health policy development. McGill Journal of Medicine, 13(1), 76-83.

Childe, V.G. (1929). The Danube in prehistory. Oxford, UK: Oxford University.

Cho, P.Y., Park, J.M., Hwang, M.K., Park, S.H., Park, Y.K., Jeon, B.Y., Kim, T.S., \& Lee, H.W. (2017). Discovery of parasite eggs in archaeological residence during the $15^{\text {th }}$ Century in Seoul, Korea. The Korean Journal of Parasitology, 55(3), 357-361.

Colwell, C. (2016). Collaborative archaeologies and descendant communities. Annual Review of Anthropology, 45, 113-127.

Dennis, S. (2013). Researching smoking in the new smoke-free: Good anthropological reasons for unsettling the public health grip. Health Sociology Review, 22(3), 282-190.

DeWitte, S.N. (2014). Differential survival among individuals with active and healed periosteal new bone formation. International Journal of Paleopathology, 7, 38-44.

Fahlman, M. (2019). Anthropology of SARS and the Leveraging of Cultural Logics in Vietnam. (M. A. Thesis). Department of Archaeology and Anthropology, University of Saskatchewan, Saskatoon.

Freeman, D. (1974). The evolutionary theories of Charles Darwin and Herbert Spencer. Current Anthropology, 15(3), 211-237.

Hodder, I. (1982a). Symbols in Action: Ethnoarchaeological Studies of Material Culture. Cambridge, UK: Cambridge University.

Hodder, I. (1982b). Theoretical archaeology: A reactionary view. In Symbolic and Structural Archaeology (pp. 1-16). Cambridge, UK: Cambridge University Press.

Hooton, E.A. (1930). The Indians of Pecos Pueblo: A Study of their Skeletal Remains. New Haven, CT: Yale University.

Engaged Scholar Journal: Community-Engaged Research, Teaching, and Learning 
Jones, J. (1876). Explorations of the Aboriginal remains of Tennessee. Smithsonian Contributions to Knowledge, 22(259), article 2. Washington, DC: Smithsonian Institute.

Kidder, A.V. (1924). An Introduction to the Study of Southwestern Archaeology with a Preliminary Account of the Excavation at Pecos. New Haven, CT: Yale University.

Kiefer, C.W. (2007). Doing Health Anthropology: Research Methods for Community Assessment and Change. New York, NY: Springer.

Lévi-Strauss, C. (1955). Tristes Tropiques. (J. Weightman \& D. Weightman, trans). London, UK: Penguin Books.

Malinowski, B. (1935). Coral Gardens and Their Magic: A Study of the Methods of Tilling the Soil and of Agricultural Rites in the Trobriand Islands. New York, NY: American Book Company.

Marklein, K.E., Leahy R., \& Crews, D. (2016). In sickness and in death: Assessing frailty in human skeletal remains. American Journal of Physical Anthropology, 161, 208-225.

Matthews, W., Wortman, J.L., \& Billings, J.S. (1893). The Human Bones of the Hemenway Collection in the United States Army Medical Museum at Washington. Washington, DC: National Academy of Sciences.

Mays, S. (1997). A perspective on osteoarchaeology in Britain. International Journal of Osteoarchaeology, 7 , 600-604.

Møller-Christensen, V. (1973). Osteo-archaeology as a medico-historical auxiliary science. Medical History, 17, 411-418.

Morgan, L.H. (1877). Ancient Society (Reprint). New York, NY: The World Publishing.

O'Shea, J. (1984). Mortuary Variability: An Archaeological Investigation. New York, NY: Academic Press.

Page-Reeves, J., Mishra, S.I., Niforatos, J., Regino, L., Gingerich, A., \& Bulten, R. (2013). An integrated approach to diabetes prevention: Anthropology, public health, and community engagement. The Qualitative Report, 18(49), 1-22.

Peoples, J., \& Bailey, G. (1997). Humanity: An Introduction to Cultural Anthropology (4 ${ }^{\text {th }}$ Ed.). London, UK: Wadsworth Publishing.

Purchase, S.L. (2016). Infectious Disease as an Indicator of Physiological Stress in the Middle Holocene CisBaikal (Masters thesis, University of Saskatchewan).

Purchase, S.L. (2018). Samantha L. Purchase. Department of Archaeology. Retrieved from www.sheffield. ac.uk/archaeology/people/phds/samantha_1_purchase

Purchase, S.L., Bazaliiskii, V.I., \& Lieverse, A.R. (2019). An innovative method to visualise mastoiditis using a hand-held x-ray system. International Journal of Paleopathology, 26, 22-26.

Purchase, S.L., Craig-Atkins, E., Nystrom, P., \& Ray, J. (2020). Visualising Mastoiditis with a Portable X-Ray System: A Preliminary Analysis. Poster for the $89^{\text {th }}$ annual meeting of the American Association of Physical Anthropology.

Radcliffe-Brown, A. R. (1952). Structure and Function in Primitive Society. Glencoe, IL: Free Press.

Roberts, C., \& Manchester, K. (2005). The Archaeology of Disease (3 ${ }^{\text {rd }}$ Ed.). New York, NY: Cornell University.

Rosman, A., \& Rubel, P.G. (1995). The Tapestry of Culture: An Introduction to Cultural Anthropology (5 ${ }^{\text {th }}$ Ed.). London, UK: McGraw-Hill.

Scheper-Hughes, N. (1994). Embodied knowledge: Thinking with the Body in Critical Medical Anthropology. In Assessing Cultural Anthropology (pp. 229-242). London, UK: McGraw-Hill.

Shackel, P. A. (2014). Stakeholders and community participation. In Encyclopedia of Global Anthropology (p. 71). New York, NY: Springer. 
Simpson, M. (2002). The plundered past: Britain's challenge for the future. In C. Fforde, J. Hubert \& P. Turnbull, (Eds.) In The Dead and their Possessions: Repatriation in Principle, Policy and Practice (pp. 199-217). London, UK: Routledge.

Stellmach, D., Beshar, I., Bedford, J., du Cros, P., \& Stringer, B. (2018). Anthropology in public health emergencies: What is anthropology good for? BMJ Global Health, 3(2), e000534.

Stocking, G.W. (1974). A Franz Boas Reader: The Shaping of American Anthropology 1883-1911. London, UK: University of Chicago.

Taylor, E.B. (1874). Primitive Culture: Researches into the Development of Mythology, Philosophy, Religion, Language, Art and Custom (Volume 1). Boston, MA: Estes and Lauriat.

Trigger, B.G. (2006). A History of Archaeological Thought (2nd Ed.). Montreal, QC: McGill University.

Truth and Reconciliation Commission of Canada (2015). Truth and Reconciliation Commission of Canada: Calls to Action. Retrieved from http://trc.ca/assets/pdf/Calls_to_Action_English2.pdf

United Nations (2007). United Nations Declaration on the Rights of Indigenous Peoples. Retrieved from https://www.un.org/development/desa/indigenouspeoples/wp-content/uploads/ sites/19/2018/11/UNDRIP_E_web.pdf

Washburn, S.L. (1951). The new physical anthropology. Transactions of the New York Academy of Science (Series 2) 12(7), 298-304.

Washburn, S.L. (1953). The new physical anthropology. Yearbook of Physical Anthropology, 7, 124-130.

Willey, G.R., \& Phillips, P. (2001). Method and Theory in American Archaeology. Tuscaloosa, AL: University of Alabama.

Wood, J.W., Holman, D.J., O’Connor, K.A., \& Ferrell, R.J. (2002). Mortality models for paleodemography. In Paleodemography: Age Distribution from Skeletal Samples (pp. 129-168). Cambridge, UK: Cambridge University.

Wood, J.W., Milner, G.R., Harpending, H.C., Weiss, K.M., Cohen, M.N., Eisenberg, L.E., Hutchinson, D.L., Jankauskas, R., Cesnys, G., Česnys, G., Katzenberg, M.A, Lukacs, J.R., McGrath, J.W., Roth, E.A., Ubelaker, D.H., \& Wilkinson, R.G. (1992). The osteological paradox: Problems of inferring prehistoric Health from Skeletal Samples [and Comments and Reply]. The University of Chicago Press Journals, 33(4), 343-370.

Engaged Scholar Journal: Community-Engaged Research, Teaching, and Learning 